\title{
JOURNAL.RU
}

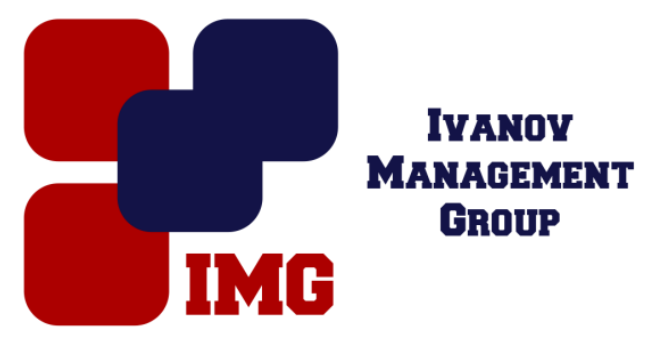

Polukhina R. North Caucasus branch of the Russian State University of Justice Krasnodar, Russia

doi: $10.18411 / \mathrm{lj}-31-05-2017-45$

idsp 000001:1j-31-05-2017-45

\section{Principle of proportionality as a fundamental principle of the international and european law in the activity of the court of arbitration for sport}

\begin{abstract}
The article enlights the question of application of the principle of proportionality in the CAS activities, which is the some kind of such general principle of international law as protection of individual rights and freedoms. The authors analyse a number of the CAS decisions, which show evolution of this principle, its development under the trend of protecting of individual rights and freedoms in the sphere of sport. The article will be interesting to everybody who study problems of international sports law and CAS activity.

Keywords: international sports law, principles of the international and European law, doping, principle of proportionality, Court of Arbitration for Sport, sportsman.

In settling disputes the Court of Arbitration for Sport (hereinafter the Court or the Panel) among other things relies on the generally recognized principles and rules of law, what is regularly reflected in the Court's decisions in the form of a special choice of law clause. In this respect, the following case can be mentioned as an example. The paragraph 15 of the decision on the case «International Olympic Committee (IOC) v. Chagnaadorj Usukhbayar» stipulates that the Court shall rule on the dispute pursuant to the IOC ADR (the International Olympic Committee's AntiDoping Rules), the applicable regulations, Swiss Law and general principles of law.

In the legal literature, the terms «general principles of law» и «generally recognized principles of the international law» are considered to be the same.
\end{abstract}


According to the theory of the international law, the following words of S.V.Chernichenko, regarding the principles of the international law, are quite appropriate here: there are «universally accepted norms of the international law of the most common nature», "which constitute the most general expression for the established practice in the sphere of the international relations, legally binding grounds of the contemporary international law, its foundations».

The prevailing view in legal doctrine is that the main principles of the international law are enshrined in the United Nations Charter (with the reservation that the full list of those principles does not exist), in the Declaration on Principles of International Law concerning Friendly Relations and Co-operation among States in accordance with the Charter of the United Nations, and also in the Final Act of the Conference on Security and Cooperation in Europe (Helsinki, 1 August 1975).

The subject matter covered by this work is a concept of human rights and fundamental freedoms as a basis of principle of proportionality in the activity of the Court of Arbitration for Sport.

The abovementioned principle (protection of human rights and fundamental freedoms) is not directly enshrined in the UN Charter. Art.1 para.3 reads as follows (CHAPTER I «Purposes and principles»): «To achieve international co-operation in solving international problems of an economic, social, cultural, or humanitarian character, and in promoting and encouraging respect for human rights and for fundamental freedoms for all without distinction as to race, sex, language, or religion». Art.55 supplements the above provisions and establishes that the United Nations shall promote universal respect for, and observance of, human rights and fundamental freedoms for all without distinction as to race, sex, language, or religion.

In the Final Act of the Conference on Security and Cooperation in Europe among other principles that need to be followed by the States the principle of respect for human rights, including freedom of thought, conscience, religion and belief, is guaranteed to all.

In the European Union's legal framework a number of generally recognized principles of the international law were reflected and specified. With regard to the concept of human rights and fundamental freedoms, the latter was elaborated through the development of the proportionality principle set out in the Treaty on the European Union. In accordance with this principle, any actions and decisions of the public authorities must be in strict compliance with their aims of activities and they should not exceed admissible limit, inter alia, while bringing someone to justice. It means that 
the seriousness of the sanction or punishment should correspond to the gravity of the offence.

At this moment in Russian scientific literature there is no research focusing on the topic. In foreign scientific literature, devoted to international sport law, this question was illustrated enough for having possibility to derive main concepts of legal nature of the proportionality principle.

In European Law with regard to the dispute settlement procedures of the Court the following understanding of the proportionality principle can be considered predominating: «The proportionality principle is widely recognized and accepted. It prohibits the taking of any measure which in view of its objective must be considered to go beyond what is appropriate and necessary. The application of the principle involves the balancing of the interests of the person or persons affected by the measure and the possibly wider social aim which it is intended to achieve. The CAS has regularly considered whether the doctrine of proportionality could be applied in reduction of a penalty. The application of fixed penalties for doping offences made it difficult to weigh the severity of the offence against the severity of the penalty. Nevertheless, as the CAS at one occasion concluded, when the circumstances of the case so allowed the appellant's sentence could properly be reduced by reference to proportionality considerations».

During several decades, the proportionality principle has been consistently forming in the Court's decisions. For better understanding the trends of the human rights protection in the international sports arbitration, it seems reasonable to analyse its evolution.

The first mentions about it we can find in the CAS awards rendered many years ago. Let's see the case W. / International Equestrian Federation (FEI). This case has nothing to do with doping offence - the subject was an abuse of horses, however, it appears desirable to consult the then position of the Court concerning the place and role of the proportionality principle.

The Court considered the question if a high level United States show jumping rider (W.) was guilty of animal cruelty, since two very small plastic pieces were found in the boot of the front right leg of the horse "B.", which could conceivably hurt it. Rider's submissions in the Court were as follows: neither he, nor his groom did put any plastic pieces in B.'s boots, and any damage or sensitiveness of the leg was not found by Dr. Kersten.

In the para. 31 of the award the Court gives a detailed explanation of its position regarding the proportionality principle importance: «...it is a widely accepted general 
principle of sports law that the severity of a penalty must be in proportion with the seriousness of the infringement. The CAS has evidenced the existence and the importance of the principle of proportionality on several occasions. In the cases TAS 91/56 (S. v. FEI) and TAS 92/63 (G. v. FEI), the CAS stated that "the seriousness of the penalty [...] depends on the degree of the fault committed by the person responsible"...In the advisory opinion TAS 93/109 of September 1994 (Fédération Française de Triathlon / International Triathlon Union), the CAS, quoting the IOC Charter against Doping in Sport, stated that all sports organizations must try to impose penalties graduated in accordance with the seriousness of the offence: “...les organisations sportives doivent toujours chercher à déterminer de quelle façon l“eathlète visé a enfreint les règlements...».

Further the Court refers to its previous decisions with the following formulation: «In the case TAS 95/141 (C. v. FINA) the CAS considered that the penalty imposed on the appellant was not proportionate to the circumstances of the case and stated that "it is the task of the sports authorities to establish the guilt of an athlete in order to fix a just and equitable sanction...».

Lastly, an explicit reference to the proportion of the penalty was also made in TAS 98/204 (R. v. FEI), where the CAS confirmed the importance of respecting this general principle of law.

After a thorough examination of the case and taking into account the fact of the absence of injury to the horse, the Panel has found that the application of the proportionality principle is necessary and the sanction should be reduced from eight to six months for W. having ability to qualify for the Sydney Olympic Games.

It is interesting to look at the case Squizzato v. FINA, considered by the Court in July 2005. On August 21 and 22, 2004, a young Italian swimmer S. participated in the European Open Water Swimming Cup Competition in Waren/Müritz, Germany. Her doping sample showed the presence of the major urinary metabolite of clostebol at low concentration. According to the 2004 Prohibited List of the World Anti-Doping Code, clostebol belongs to the class S4.1.a (anabolic agent, anabolic androgenic steroids).

It subsequently became apparent that S. used a cream "Trofodermin" which she applied to her foot to fight against skin affection unaware that it contains the prohibited substance. As the swimmer claimed in the Court, the cream did not enhance the athlete's capacity and nor it favoured her performance. S. requested the Panel to acquit her from the charge, or in any event, to reduce the sanction within the limits of the suspension already inflicted by the Italian Swimming Federation 
In its judgement in the case the Court suggested a number of statements concerning the proportionality principle, namely:

- Para. 3 of the Court's judgement: substantial elements of the doctrine of proportionality have been implemented in the body of rules and regulations of many national and international sport federations by adopting the World Anti-Doping Code ((hereinafter the Code), which provides a mechanism for reducing or eliminating sanctions i.a. in cases of "no fault or negligence" or "no significant fault or negligence" on the part of the suspected athlete.

- Para. 4 of the Court's judgement: a mere "uncomfortable feeling" alone that a one year penalty is not the appropriate sanction cannot itself justify a reduction of the sanction. The individual circumstances of each case must always hold sway in determining any possible reduction. Nevertheless, the implementation of the principle of proportionality as given in the Code closes more than ever before the door to reducing fixed sanctions. Therefore, the principle of proportionality would apply if the award were to constitute an attack on personal rights which was serious and totally disproportionate to the behaviour penalised.

- Para. 44 of the Court's judgement: the Panel notes that it is a widely accepted general principle of sports law that the severity of a penalty must be in proportion with the seriousness of the infringements. The CAS has evidenced the existence and the importance of the principle of proportionality on several occasions.

- Para. 48 of the Court's judgement: the mere fact that regulations of a sport federation derive from the World Anti-Doping Code does not change the nature of these rules. They are still - like before - regulations of an association which cannot (directly or indirectly) replace fundamental and general legal principles like the doctrine of proportionality a priori for every thinkable case.

In this case, building upon the proportionality principle, the Court decided that fairness required the sanction should not last more than one year.

If we refer to the decisions, issued by the Court in 10 years, we can clearly see that the position of the Court has not changed. In a case «Public Joint-Stock Company "Football Club Metalist" v. UEFA \& PAOK FC» the Court in the para.5 of the decision made the following statement: «it is a recognised principle in CAS jurisprudence that a sanction must comply with the principle of proportionality in the 
sense that there must be a reasonable balance between the kind of misconduct and the sanction. Put differently, the severity of a sanction must be proportionate to the offence committed. To be proportionate, the sanction must not exceed what is reasonably required in the search of the justifiable aim. Any party alleging disproportionality of a sanction bears the burden of proof for its allegation».

Based on the above, we can assert that over the years the position of the Court has remained unchanged and, even more so, is constantly being improved with respect to the assessment of the particular circumstances in every case.

In order to highlight the different approaches in the foreign legal doctrine, it seems fair to outline the position under which the Court does not make full use of the possibility of applying the proportionality principle given by the Code. For example, the Dutch lawyer Houben J. supports the idea that article 10.5. of the Code, specially dedicated to the mitigation of the athlete's responsibility (in cases of "no fault or negligence" or "no significant fault or negligence"), is not easily enforceable because it can be used only in the exceptional circumstances and not in the majority of cases (this is required by the provisions of the Code). The proportionality doctrine has lost its importance because CAS does not interpret it correctly. In addition, at the time of the writing of the J.Houben's paper the Court has never used exceptional circumstances concept.

However, it must be noted that the author refers to the first version of the Code, which entered into force in 2003. The 3rd revision, in force since 2015, does not contain a clause stating that those mitigating factors can't be applied in most cases, it was replaced by the new one (comment to Article 10.4): «This Article and Article 10.5.2 apply only to the imposition of sanctions; they are not applicable to the determination of whether an anti-doping rule violation has occurred. They will only apply in exceptional circumstances, for example, where an Athlete could prove that, despite all due care, he or she was sabotaged by a competitor».

One recent example of the Court's practical application of the proportionality principle may be given. In 2016 the Court considered the case of Maria Sharapova whose «A» sample collected from her at the Tournament had tested positive for the presence of Meldonium (Meldonium is a prohibited, non-specified substance included at S4 (Hormone and Metabolic Modulators) in the list of prohibited substances). In her appeal, this elite female athlete claimed that in the circumstances of the case, the Panel should reduce the ineligibility to a shorter period, consistent with the principle of proportionality. 
Having considered all of the appellant's reasons, the Panel has determined that the appropriate length of sanction is fifteen (15) months; in other words, the Panel has reduced her sanction on the basis of NSF (no significant fault) by nine (9) months.

Taking everything into consideration, we can stated that in the sphere of the international sports law the application of the proportionality principle is due to the need for the appropriate evaluation of the factual background of the dispute and degree of the person's fault (what is impossible for establishing by law). This means some extent of subjectivity of the arbiters and inevitably affect its implementation.

However, regardless of the position and on the basis of the Court's multy-year findings, we can confidently state that when imposing sanctions on athletes the fundamental issue is an application the international and European law principles, especially when it comes to a conflict between the severity of the offence and the severity of the penalty for doping. 
1. United Nations Charter.

2. Declaration on Principles of International Law concerning Friendly Relations and Cooperation among States in accordance with the Charter of the United Nations.

3. Final Act of the Conference on Security and Cooperation in Europe (Helsinki, 1 August 1975).

4. World Anti-Doping Code. Version 1st (2003), version 2nd (2009) and version 3rd (2013).

5. European international law. Ed. by U. Kolosov, E. Krivchikova, P. Savaskov. Moscow. 2009.

6. European law. Law of the European Union and legal enforcement of human rights protection. Ed. by L. Entin. Moscow. 2007.

7. T. Matveeva. International law. Course of lectures. Moscow. 2001.

8. R.Polukhina «Mitigating factors as a fundamental principle of the imposing sanctions on athletes for doping offences in the activity of the Court of Arbitration for Sport

9. S.V.Chernichenko. Norms and principles of the international law. Diplomatic Academy, Ministry of Foreign Affairs of the Russian Federation. Center of the International Law and Humanitarian Problems. Moscow. 1998.

10. Panagiotopoulos D. Sports law. Lex sportive and Lex olympica. Athens. 2011.

11. Houben J. Proportionality in the World Anti-Doping Code: Is There Enough Room for Flexibility? // International sports law journal. 2007. Vol. 1-2.

12. Hreinsson P. The Handbook of EEA Law. Switzerland. 2016.

13. Schweizer M. Nudging and the Principle of Proportionality. / Mathis K., Tor A. (eds.). Nudging - Possibilities, Limitations and Applications in European Law and Economics. Switzerland. 2016.

14. Soek J. The strict liability principle and the human rights of athletes in doping cases. The Hague. 2006.

15. CAS 99/A/246 W. / International Equestrian Federation (FEI), award of 11 May 2000.

16. CAS 2005/A/830 S. v. FINA, award of 15 July 2005.

17. CAS 2013/A/3297 Public Joint-Stock Company "Football Club Metalist" v. UEFA \& PAOK FC, award of 29 November 2013.

18. AD 16/008 International Olympic Committee (IOC) v. Chagnaadorj Usukhbayar oт 20 августа 2016 г.

19. CAS 2016/A/4643. Maria Sharapova v. ITF, award of 30 September 2016. 